\title{
Nonlinear Relationships between Taiwan VIX Index and the Intraday Ordering Behavior of Stock Index Options
}

\author{
Jack J. W. Yang ${ }^{1}$, Chia-Hsing Huang ${ }^{2} \&$ Chi-Hui Wang ${ }^{1}$ \\ ${ }^{1}$ Department of Finance, National Yunlin University of Science and Technology, Yunlin, Taiwan \\ ${ }^{2}$ SolBridge International School of Business, South Korea \\ Correspondence: Chia-Hsing Huang, SolBridge International School of Business, 151-13 Samsung 1-dong, Dong-gu, \\ Daejeon, 300-814, South Korea. Tel: 82-42-630-8527. E-mail: koreasing@solbridge.ac.kr
}

Received: June 21, 2013

Accepted: July 20, 2013

Online Published: July 30, 2013

doi:10.5430/bmr.v2n3p68

URL: http://dx.doi.org/10.5430/bmr.v2n3p68

\begin{abstract}
Threshold vector error correction model is used to study the nonlinear relationships between market volatility expectations and ordering behavior. Futures price, market volatility expectations, and derivatives ordering behavior data are used in the study. The intraday data of the VIX index, stock index futures price, and stock index options ordering volume from the Taiwan Futures Exchange are used for the study. Research results show the existence of asymmetric impacts of lagged VIX index on futures price, lagged VIX index on put options buy order to sell order volume ratio, lagged futures price on VIX index, lagged call options buy order to sell order volume ratio on VIX index, and lagged put options buy order to sell order volume ratio on VIX index when using VIX index as threshold.
\end{abstract}

Keywords: VIX, Futures, Options, Ordering behavior, Volume

\section{Introduction}

Threshold vector error correction model is used to study the nonlinear relationships between market volatility expectations and ordering behavior. Futures prices, market volatility expectations, and derivatives ordering behavior data are used in the study. The market volatility expectation is captured by the VIX index. The VIX index is forward looking and it represents the market's expectation of future volatility. The investor expectation of market total risk is captured by the VIX index. The VIX index affects the expected return of stock markets (Durand, Lim \& Zumwalt, 2011). The VIX index (implied volatility in the options markets) provides better forecast quality than historical volatility (Corrado \& Miller, 2005; Carr \& Wu, 2006). Large amount of options trading are from hedgers. When the stock market index is expected to plunge, the hedgers will buy index puts for portfolio insurance (Whaley, 2009). The VIX index will increase when the stock index options price increases since the options price is positively related to volatility.

Spot and futures are found to have contemporaneous and lead-lag relationships in linear models (Kawaller, Koch, \& Koch, 1987; Herbst, McCormack, \& West, 1987; Finnerty \& Park, 1987; Stoll \& Whaley, 1990; Chan, 1992; Gannon, 2005; Illueca \& Lafuente, 2007; Kavussanos, Visvikis, \& Alexakis, 2008; Athanasios, 2010; Yang, Yang, \& Zhou, 2012) and nonlinear models (Sarno \& Valente, 2000; Antoniou, Pescetto, \& Violaris, 2003; McMillian \& Speight, 2006). However, there is no consistent conclusion on the lead-lag relationships between spot and futures. As the lead-lag relationships between spot and futures are affected by investor structure. The futures market will lead the spot market if the futures market has more institutional investor, and vice versa (Bohl, Salm, \& Schuppli, 2011).

The linear relationships between volatility and trading volume are studied by Karpoff (1987), Park, Switzer, \& Bedrossian (1999), Lee \& Rui (2002), Wagner \& Marsh (2005). Researches show that the implied volatility has relationships with price and return volatility. Implied volatility provides important information for the price and return volatility (Hansen, 2001; Christensen \& Hansen, 2002; Mayhew \& Stivers, 2003; Dennis, Mayhew, \& Stivers, 2006; Chung, Tsai, Wang, \& Weng, 2011).

Empirical study shows that VIX index and stock index return has negative contemporaneous relationship (Fleming, Ostdiek, \& Whaley, 1995). The relationships study between VIX futures price and VIX index are shown to have linear and nonlinear two way causalities (Shu \& Zhang, 2012). Most of the researches study the relationships between implied volatility and trading volume, but not focus on the relationships between implied volatility and the ordering behavior in the derivatives markets. The market expected volatility and put options ordering volume are 
found to be linearly affected by the futures price, and the call options ordering volume is linearly affected by VIX (Huang, Chang, \& Wang, 2013). It is predicted that the market expected volatility and options ordering behavior have nonlinear relationships. Nonlinear relationships between implied volatility, futures price and ordering behavior are the main focus of this paper.

\section{Data}

Intraday data of the Taiwan stock index options (Taiwan Stock Exchange Capitalization Weighted Stock Index Options, TAIEX Options) and Taiwan stock index futures (Taiwan Stock Exchange Capitalization Weighted Stock Index Futures, TAIEX Futures) from January 1 to December 31 of the year 2008 are taken from TEJ database. Intraday data of the Taiwan VIX (volatility index for TAIEX options) is taken from the Taiwan Futures Exchange. The VIX market opening and closing time are 8:45 and 13:45 respectively. Taiwan VIX index is constructed by the same formula with the Chicago Board Options Exchange (CBOE) VIX index from the year 2003.

Synchronized VIX, cumulative buy order volume, cumulative sell volume, and cumulative trading volume time series are constructed. The first difference of VIX index (VIXR), the first difference of futures price (FR), the first difference of call options buy order to sell order volume ratio (CBSR), the first difference of put options buy order to sell order volume ratio (PBSR), and the first difference of call options trading volume to put options trading volume (CPVR) are used in this paper.

Descriptive statistics for the percentage change (first difference) time series are shown in table 1. Jarque-Bera normality tests for normality show rejection of the null hypothesis. Therefore, all five time series are not normally distributed.

Table 1. Descriptive statistics for the percentage change time series

\begin{tabular}{|c|c|c|c|c|c|}
\hline & VIXR & FR & CBSR & PBSR & CPVR \\
\hline Mean & 0.004 & -0.008 & 0.000 & 0.048 & -0.095 \\
\hline Maximum & 18.922 & 6.566 & 125.132 & 484.678 & 138.797 \\
\hline Minimum & -22.793 & -7.203 & -55.585 & -152.606 & -477.688 \\
\hline Std. Dev. & 1.148 & 0.483 & 7.663 & 12.928 & 12.674 \\
\hline Skewness & 1.882 & -0.869 & 5.903 & 11.544 & -8.785 \\
\hline Kurtosis & 82.316 & 52.109 & 73.109 & 379.255 & 332.038 \\
\hline Jarque-Bera & $1941215^{* * *}$ & $743438.2^{* * *}$ & $1556217^{* * *}$ & $43405957^{* * *}$ & $33165050^{* * *}$ \\
\hline Observations & 7389 & 7389 & 7389 & 7331 & 7331 \\
\hline
\end{tabular}

Notes: 1. VIXR: percentage change of VIX 2. FR: futures price return 3. CBSR: percentage change of call options buy order volume to sell order volume ratio 4. PBSR: percentage change of put options buy order volume to sell order volume ratio 5. CPVR: percentage change of call options trading volume to put options trading volume ratio

\section{Research Method}

Augmented Dickey-Fuller test (Sims, 1988) and Phillips-Perron test (Phillips \& Perron, 1988) are used for the linear unit root tests. The ADF and PP tests are for the null hypothesis that a time series is I(1). Engle-Granger unrestricted estimation is used for the cointegration test. Cointegration represents the integrated series for which a linear combination exists that is stationary (Engle \& Granger, 1987). This can be interpreted economically as the presence of a long-run equilibrium, stable relationship between the variables. Granger representation theorem states that cointegrated variables have a vector error correction model (VECM) representation. That can be seen as a VAR model including a variable representing the deviations from the long-run equilibrium.

This VECM representation can be used to estimate how the variables adjust deviations towards the long-run equilibrium, to test for Granger causality and to determine the impacts of shocks to the variables using impulse response functions. In a system with more than $\mathrm{k}$ variables may has (k-1) cointegrating relationships. Hence the vector A of adjustment speed parameters (also called loading matrix) and the vector B of cointegrating values become matrices 1 . The matrix of their product, corresponding to the parameters of the lagged vector, is singular with rank equal to the number of cointegrating relationships.

It is possible that nonlinear asymmetric adjustment processes exist between the nonstationary variables in the linear models. Nonlinear models are better solutions to capture nonlinear cointegration relationship between variables 
(Enders \& Granger, 1998; Enders \& Siklos, 2001). Following Enders \& Granger (1998), Enders \& Siklos (2001), the nonlinear relationships between variables can be studied by the threshold vector error correction model (Balke \& Fomby, 1997). The threshold vector error correction model (TVECM) is defined in equation (1).

$$
\Delta \mathrm{Y}_{\mathrm{t}}=\mathrm{a}_{0}^{(\mathrm{j})}+\alpha^{(\mathrm{j})}\left[\beta^{\prime} \mathrm{Y}_{\mathrm{t}-1}\right]+\sum_{\mathrm{i}=1}^{\mathrm{p}-1} \mathrm{~A}_{\mathrm{i}}^{(\mathrm{j})} \Delta \mathrm{Y}_{\mathrm{t}-\mathrm{i}}+\varepsilon_{\mathrm{t}}^{(\mathrm{j})}, \mathrm{r}^{(\mathrm{j}-1)}<\mathrm{Z}_{\mathrm{t}-\mathrm{d}} \leq \mathrm{r}^{(\mathrm{j})}, \mathrm{j}=1,2, \cdots \mathrm{k}
$$

Where

$\mathrm{a}_{0}^{(\mathrm{j})}$ : constant in regime $\mathrm{j}$

$\alpha^{(j)}$ : adjustment speed to long term equilibrium in regime $\mathrm{j}$

$\beta$ : cointegration vector

$A_{i}^{(j)}$ : coefficient vector in regime $j$

$\mathrm{Z}_{\mathrm{t}-\mathrm{d}}=\beta^{\prime} \mathrm{Y}_{\mathrm{t}-\mathrm{d}}:$ threshold variable

$\mathrm{d}:$ number of lag

$\mathrm{r}^{(\cdot)}$ : threshold value $(-\infty=\mathrm{r}(0)<\mathrm{r}(1)<\ldots<\mathrm{r}(\mathrm{k})=\infty)$

$\left\{\varepsilon_{\mathrm{t}}^{(\mathrm{j})}\right\}$ : vector of normally distributed disturbances

The Threshold Vector Error Correction Model with two-regime, a single cointegrating vector and a threshold effect in the error-correction term is shown in equation (2). The asymptotic null distribution of the Sup-LM test is used to test the presence of a threshold (Hansen \& Seo, 2002).

$\Delta \mathrm{Y}_{\mathrm{t}}=\Omega_{1}^{\prime} \mathrm{X}_{\mathrm{t}-1}(\beta) \mathrm{d}_{\mathrm{t}}(\beta, \mathrm{r})+\Omega_{2}^{\prime} \mathrm{X}_{\mathrm{t}-1}(\beta)\left(1-\mathrm{d}_{\mathrm{t}}(\beta, \mathrm{r})\right)+\varepsilon_{\mathrm{t}}$

The VIXR and FR equations can be shown in the following.

$$
\begin{array}{ll}
\Delta \operatorname{VIXR}_{\mathrm{t}}=\mathrm{a}_{1}^{(1)}+\alpha_{1}^{(1)} \mathrm{Z}_{\mathrm{t}-1}+\sum_{\mathrm{i}=1}^{\mathrm{p}-1} \mathrm{~A}_{11, \mathrm{i}}^{(1)} \Delta \mathrm{VIXR}_{\mathrm{t}-\mathrm{i}}+\sum_{\mathrm{i}=1}^{\mathrm{p}-1} \mathrm{~A}_{12, \mathrm{i}}^{(1)} \Delta \mathrm{FR}_{\mathrm{t}-\mathrm{i}}+\varepsilon_{1}^{(1)} & \\
\Delta \mathrm{FR}_{\mathrm{t}}=\mathrm{a}_{2}^{(1)}+\alpha_{2}^{(1)} \mathrm{Z}_{\mathrm{t}-1}+\sum_{\mathrm{i}=1}^{\mathrm{p}-1} \mathrm{~A}_{21, \mathrm{i}}^{(1)} \Delta \mathrm{VIXR}_{\mathrm{t}-\mathrm{i}}+\sum_{\mathrm{t}-1}^{\mathrm{p}-1} \mathrm{~A}_{22, \mathrm{i}}(3) & \\
\Delta \mathrm{VIXR}_{\mathrm{t}-\mathrm{i}}=\mathrm{a}_{1}^{(2)}+\alpha_{1}^{(1)} \mathrm{Z}_{\mathrm{t}-1}+\sum_{\mathrm{i}=1}^{\mathrm{p}-1} \mathrm{~A}_{11, \mathrm{i}}^{(2)} \Delta \mathrm{VIXR}_{\mathrm{t}-\mathrm{i}}+\sum_{\mathrm{i}=1}^{\mathrm{p}-1} \mathrm{~A}_{12, \mathrm{i}}^{(2)} \Delta \mathrm{FR}_{\mathrm{t}-\mathrm{i}}+\varepsilon_{1}^{(2)} & \mathrm{Z}_{\mathrm{t}-1}>\mathrm{C}_{2}
\end{array}
$$

\section{Empirical Results}

The Augmented Dickey-Fuller (ADF) test and Phillips \& Perron (PP) test results are shown in Table 2. Unit root tests in table 2 show that both VIX index and futures price have a unit root at level. After taking first difference, all of the variables become stationary. It is shown in Table 2 that only VIX and futures price are I(1). Engle-Granger unrestricted estimation is used for the cointegration tests. It is shown in Table 3 that VIXR and the other four variables are all rejected at $1 \%$ significance level. Therefore, TVECM model is used for the study. 
Table 2. Unit root test

\begin{tabular}{|c|c|c|c|c|c|}
\hline & VIX & Futures Price & CBS & PBS & $\mathrm{CP}$ \\
\hline \multicolumn{6}{|l|}{ Level } \\
\hline $\mathrm{ADF}$ & -1.893 & -0.273 & $-9.062^{* * *}$ & $-6.963^{* * *}$ & $-72.526^{* * *}$ \\
\hline PP & -1.937 & -0.294 & $-40.272^{* * *}$ & $-13.000^{* * *}$ & $-98.087^{* * *}$ \\
\hline \multicolumn{6}{|c|}{$1^{\text {st }}$ Differences } \\
\hline $\mathrm{ADF}$ & $-92.533^{* * *}$ & $-89.577^{* * *}$ & $-21.214^{* * *}$ & $-17.858^{* * *}$ & $-48.488^{* * *}$ \\
\hline PP & $-92.542^{* * *}$ & $-89.517^{* * *}$ & $-349.749^{* * *}$ & $-165.583^{* * *}$ & $-76.013^{* * *}$ \\
\hline
\end{tabular}

Notes: 1. CBS: call options buy order volume to sell order volume ratio 2. PBS: put options buy order volume to sell order volume ratio 3. CP: call options trading volume to put options trading volume ratio 4 . $^{* * *}$ denotes significance at the $\leqq 0.01$ level. 5 . 5\% test critical value:- 2.862

Table 3. Engle-Granger unrestricted Cointegration test

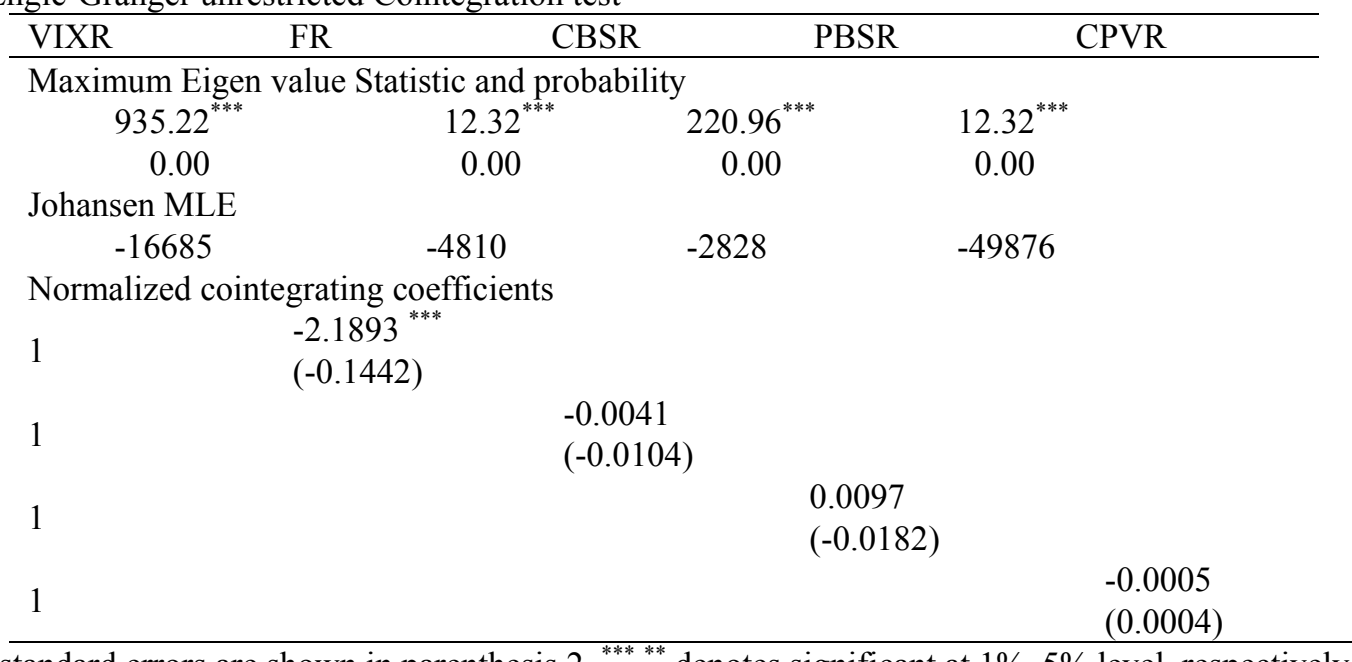

Notes: 1. standard errors are shown in parenthesis $2 .{ }^{* * * * *}$, denotes significant at $1 \%, 5 \%$ level, respectively

3. MacKinnon and Haug (1999) p-values

The threshold value is estimated by two models, i.e. single threshold and two thresholds models. If there is one threshold, the least square (LS) estimates are obtained by minimizing the concentration LS. With maximum autoregressive order for low regime $\mathrm{mL}=1$ and maximum autoregressive order for high regime $\mathrm{mH}=1$, the sum of square (SSR) of 1675 possible threshold values within regions with sufficient number of observations (15\%) and delay (1) are estimated. And the one that minimizes the SSR is the estimator. The threshold is 40.16 in the one threshold case by the grid search. Under the same SSR value, the two thresholds are 33.64 and 40.16 in the two thresholds situation. To be consistent with the empirical VIX point of 40, two regimes model with a threshold point 40.16 is used in this paper.

Table 4. Boundaries and number of observation for each variable with VIX and VECM lags

\begin{tabular}{lcrrrr}
\hline & Thresholds & \multicolumn{4}{c}{ observations } \\
& & FP & CBSR & PBSR & CPVR \\
\hline Regime 1 & $(22.56 ; 40.16]$ & 5464 & 5464 & 5464 & 5464 \\
Regime 2 & $(40.16 ; 61.87]$ & 1925 & 1925 & 1869 & 1869
\end{tabular}

\begin{tabular}{lllll} 
Lag for variables & 14 & 36 & 36 & 36 \\
\hline
\end{tabular}

The boundaries and number of observations for each variable and VECM lags are shown in Table 4 . To avoid autocorrelation, the VECM lags are determined by assessing the pairs of VIXR and the other variables for 36 lags until there is no residual correlogram at 1\% significant level. Schwartz Bayesian Information Criterion (SBC) is used to determine the optimal lag length for the VAR model. To have appropriate deterministic components in the system, 
the log likelihood value is used to determine if there is no intercept, trend in cointegrating equation (CE), or VAR.

The results of Hansen threshold nonlinearity test based on the long-run relationship for VIX after bootstrap 100 times are shown in Table 5.

Table 5. Hansen test of linearity against $\operatorname{SETAR}(2)$ and $\operatorname{SETAR}(3)$ for VIX

\begin{tabular}{|c|c|c|c|c|c|c|c|}
\hline \multirow[b]{2}{*}{ Test } & \multirow[b]{2}{*}{$P$ value } & \multicolumn{3}{|c|}{ Critical values } & \multicolumn{2}{|c|}{ Threshold of original series } & \multirow{2}{*}{$\begin{array}{l}\text { SSR of original } \\
\text { series }\end{array}$} \\
\hline & & 0.9 & 0.95 & 0.99 & th1 & th2 & \\
\hline \multicolumn{8}{|c|}{1 regime against 2 SETAR(2) } \\
\hline 7.81 & 0.44 & 12.44 & 15.93 & 19.46 & 40.16 & NA & 1356.09 \\
\hline \multicolumn{8}{|c|}{1 regime against 3 SETAR(3) } \\
\hline 22.44 & 0.10 & 21.44 & 24.12 & 33.19 & 33.64 & 40.16 & 1353.41 \\
\hline
\end{tabular}

Easy to read and concise versions, with only information of six lag coefficients, for the Threshold Vector Error Correction Model (TVECM) from VIXR and FR, VIXR and CBSR, VIXR and PBSR, and VIXR and CPVR are shown in Tables 6 to 9, respectively.

It is shown in Table 6 that the error correction cointegration equation coefficients for VIXR and FR are -0.5876 and 0.2301 in regime 1; and -0.5104 and -0.2653 in regime 2 . In both regimes, VIXR and FR have significant long-run equilibrium adjustment effects. And VIXR has higher adjustment speed than FR. In the long-run equilibrium relationship, cointegration equation shows that, in regime 1 , when $V I X R_{t}>2.7366 F R_{t}$, VIXR moves down and FR moves up to approach long-run equilibrium. In regime 2, when $V I X R_{t}>-2.1741 F R_{t}$, VIXR and FR move down to approach long-run equilibrium.

In the short run momentum relationship, VIXR equation shows that, in regime 1, the lagged VIXR and the lagged FR have significant negative impacts on VIXR. FR equation also shows that, in regime 1, the lagged VIXR has significant negative impacts and the lagged FR also has significant negative impacts on FR. This implies that, using VIX as threshold, both the lagged VIXR and lagged FR have significant negative impacts on VIXR and FR in regime 1. This also means that, in regime 1, VIXR and FR have two way lead-lag relationships. In regime 1, the impacts of lagged VIXR and lagged FR on VIXR are greater than the impacts of lagged VIXR and lagged FR on FR.

Interestingly, VIXR equation shows that, in regime 2, the lagged VIXR has significant negative impacts and the lagged FR has significant positive impacts on VIXR. FR equation shows that, in regime 2, the lagged VIXR has significant positive impacts and the lagged FR has significant negative impacts on FR. This indicates that, in regime 2, VIXR and FR have two way lead-lag relationships. And more importantly, in regime 1, the lagged VIXR has negative impacts on FR, and lagged FR has negative impacts on VIXR. However, the impacts are in different direction in the higher VIX level, i.e. regime 2. In regime 2, the lagged VIXR has positive impacts on FR, and the lagged FR has positive impacts on VIXR. The results show that the impacts of lagged VIXR on FR and the impacts of lagged FR on VIXR are both negative when VIX is lower than the threshold. The impacts of lagged FR on VIXR and the impacts of lagged VIXR on FR are both positive when VIX is larger than the threshold.

The TVECM model estimations of VIXR and CBSR are shown in Table 7. Table 7 shows that the error correction cointegration equation coefficients for VIXR and CBSR are -0.1397 and -3.1668 in regime 1 ; and -0.0088 and -1.4162 in regime 2 . The error correction cointegration equations show that, in both two regimes, the coefficients for VIXR and CBSR are both negative. The long-run adjustment effect of VIXR is significant only in regime 1, but not in regime 2. This indicates that only VIXR has long-run equilibrium adjustment power in regime 1 . The long-run equilibrium adjustment effects for CBSR are significant in both regimes. In regime 1, CBSR has higher adjustment speed than VIXR. CBSR coefficient of regime 1 is 2 times greater than the CBSR coefficient of regime 2. This indicates that, when VIX increases, CBSR will decrease more in regime 1 than in regime 2 to reach the long-run equilibrium. This also implies that in different regimes, the VIXR and CBSR equations show different long-run equilibrium relationship and adjustment speed.

The short-term momentum relationship results show that the lagged VIXR has significant negative impacts on VIXR in the VIXR equations in both regimes. The lagged VIXR has significant positive impacts on CBSR in the CBSR equations in both regimes and the lagged CBSR has significant positive impacts on CBSR in the CBSR equations in both regimes. The lagged CBSR has significant positive impacts on VIXR in regime 1, but no significant impacts on VIXR in regime 2. This indicates that VIXR and CBSR have two way lead-lag relationships in regime 2, but lagged 
CBSR leads VIXR in regime 1. The results show that the lagged CBSR has positive impacts on VIXR when VIX is smaller than the threshold and the lagged CBSR has negative impacts on VIXR when VIX is larger than the threshold.

The results of TVECM model for VIXR and PBSR are shown in Table 8. The error correction coefficients for VIXR and PBSR are $(-0.0121,-0.7128)$ in regime 1 and $(-0.1424,5.4671)$ in regime 2 . In regime 1 , when $V_{I X} R_{t}>$ $-2.6936 P B S R_{t}$, VIXR and PBSR decline toward the same direction to reach the long-run equilibrium situation and PBSR has faster adjustment speed than VIXR for long-run equilibrium. However, in regime 2, when $V I X R_{t}>$ $0.2754 P B S R_{t}$, VIXR will decline and PBSR will increase to reach long-run equilibrium situation. This implies that, in regime 2, when VIX is above the threshold, VIXR and PBSR have negative relationships. In both regimes, PBSR has faster adjustment speed than VIXR to reach long-run equilibrium situation.

In the short-term momentum relationships, VIXR equation shows that the lagged VIXR has significant negative impacts and the lagged PBSR has significant positive impacts on VIXR in regime 1. PBSR equation shows that, in regime 1, the lagged VIXR has significant positive impacts on PBSR and the lagged PBSR has significant positive impacts on PBSR. This indicates that, using VIX as threshold, the lagged VIXR has positive impacts on PBSR in regime 1. PBSR equation shows that VIXR and PBSR have significant positive impacts on PBSR in regime 1. This indicates that VIXR and PBSR have two way lead-lag relationships in regime 1. VIXR equation shows that, in regime 2, both the lagged VIXR and the lagged PBSR have significant negative impacts on VIXR. PBSR equation shows that, in regime 2, the lagged VIXR has significant negative impacts on PBSR, and the lagged PBSR has significant positive impacts on PBSR. This indicates that VIXR and PBSR have two way lead-lag relationships in regime 2. The results show that, using VIX as threshold, the lead lag relationships between VIXR and PBSR are in different directions in two regimes. The results show that the impacts of lagged VIXR on PBSR and the impacts of lagged of PBSR on VIXR are both positive when VIX is smaller than the threshold. And the impacts of lagged VIXR on PBSR and the impacts of lagged PBSR on VIXR are both negative when VIX is larger than the threshold.

The results of TVECM model for VIXR and CPVR are shown in Table 9. The error correction coefficients for VIXR and CPVR are $(0.0012,-0.1733)$ in regime 1 and $(-0.1514,-7.1163)$ in regime 2 . In regime 1 , when $V_{I X} R_{t}>$ $-11.6343 C P V R_{t}$, CPVR declines to reach long-run equilibrium, and VIXR has insignificant power to reach long-run equilibrium. In regime 2, when $V I X R_{t}>-0.2376 C P V R_{t}$, both VIXR and CPVR decline to reach long-run equilibrium and CPVR has faster adjustment speed than VIXR.

In the short-term momentum relationships, VIXR equation shows that the lagged VIXR has significant negative impacts on VIXR, and the lagged CPVR has insignificant negative impacts on VIXR in regime 1. CPVR equation shows that, in regime 1, the lagged VIXR has insignificant positive impacts on CPVR and the lagged CPVR has significant positive impacts on CPVR. This implies that, using VIX as threshold, the lagged VIXR has insignificant positive impacts on CPVR; and the lagged CPVR has insignificant negative impacts on VIXR in regime 1. VIXR equation shows that, in regime 2, the lagged VIXR has significant negative impacts on VIXR, and the lagged CPVR has significant positive impacts on VIXR. CPVR equation shows that, in regime 2, both the lagged VIXR and the lagged CPVR have significant positive impacts on CPVR. This implies that, using VIX as threshold, the lagged CPVR has significant positive impacts on VIXR and the lagged VIXR has significant positive impacts on CPVR in regime 2. The results show that VIXR and CPVR have significant two lead-lag relationships in regime 2. The lagged VIXR has insignificant positive impacts on CPVR and the lagged CPVR has insignificant negative impacts on VIXR when VIX is smaller than the threshold. The lagged VIXR has positive impacts on CPVR and the lagged CPVR has positive impacts on VIXR when VIX is larger than the threshold.

Figure 1 shows non-linear impulse response of VIXR to Cholesky one s.d. innovations with respect to FR, CBSR, PBSR and CPVR, respectively in two regimes. In regime 1 , the size of the shock is $(1.07 \%,-0.2 \%)$; and in regime 2, the size of the shock is $(1.34 \%,-0.15 \%)$. VIXR reflects the shock more than other variables, especially from period 1 to period 2. In period 2, VIXR reflects the shock to negative range in regime 1. FR reflects the shock in different regime. In regime 1, FR reflects the shock all above the positive range. In regime 2, FR reflects the shock all under the negative range. The CBSR reflects the shock differently in two regimes. In regime 1, the shock value is negative or near zero. In regime 2, from period 1 to 4 , the shock values are all positive, however, the shock values are negative after period 5. The results of impulse response to PBSR and CPVR are almost the same situation in regime 1 and 2. These two variables are closed to horizontal and converge to zero. 
Table 6. Results of the TVECM model for VIXR and FR

\begin{tabular}{|c|c|c|c|c|}
\hline & Regime 1 & & Regime 2 & \\
\hline \multicolumn{5}{|l|}{ VIXR equation } \\
\hline $\mathrm{Z}_{\mathrm{t}-1}$ & $-0.5876^{* * *}$ & $(-14.900)$ & $-0.5104^{* * *}$ & $(-7.414)$ \\
\hline $\operatorname{VIXR}_{t-1}$ & $-0.5324^{* * *}$ & $(-13.563)$ & $-0.4776^{* * *}$ & $(-6.998)$ \\
\hline $\operatorname{VIXR}_{\mathrm{t}-2}$ & $-0.5337^{* * *}$ & $(-13.574)$ & $-0.4566^{* * *}$ & $(-6.779)$ \\
\hline $\operatorname{VIXR}_{t-3}$ & $-0.5085^{* * *}$ & $(-12.968)$ & $-0.3825^{* * *}$ & $(-5.772)$ \\
\hline $\operatorname{VIXR}_{t-4}$ & $-0.5012^{* * *}$ & $(-12.899)$ & $-0.3989^{* * *}$ & $(-6.172)$ \\
\hline $\mathrm{VIXR}_{\mathrm{t}-5}$ & $-0.4781^{* * *}$ & $(-12.414)$ & $-0.3264^{* * *}$ & $(-5.189)$ \\
\hline VIXR $_{t-6}$ & $-0.4719^{* * *}$ & $(-12.505)$ & $-0.3068^{* * *}$ & $(-5.046)$ \\
\hline $\mathrm{FR}_{\mathrm{t}-1}$ & $-1.5402^{* * *}$ & $(-14.405)$ & $0.9930^{* * *}$ & ( 6.699) \\
\hline $\mathrm{FR}_{\mathrm{t}-2}$ & $-1.4993^{* * *}$ & $(-14.140)$ & $0.7763^{* * *}$ & $(5.325)$ \\
\hline $\mathrm{FR}_{\mathrm{t}-3}$ & $-1.4294^{* * *}$ & $(-13.643)$ & $0.7030^{* * *}$ & ( 4.942) \\
\hline $\mathrm{FR}_{\mathrm{t}-4}$ & $-1.3686^{* * *}$ & $(-13.288)$ & $0.6389^{* * *}$ & ( 4.646) \\
\hline $\mathrm{FR}_{\mathrm{t}-5}$ & $-1.2417^{* * *}$ & $(-12.313)$ & $0.5522^{* * *}$ & ( 4.161$)$ \\
\hline $\mathrm{FR}_{\mathrm{t}-6}$ & $-1.1732^{* * *}$ & $(-11.970)$ & $0.4904^{* * *}$ & ( 3.849$)$ \\
\hline Adj. R-squared & \multicolumn{2}{|l|}{0.573} & \multicolumn{2}{|l|}{0.486} \\
\hline \multicolumn{5}{|l|}{ FR equation } \\
\hline$Z_{t-1}$ & $0.2301^{* * *}$ & ( 16.298) & $-0.2653^{* * *}$ & $(-7.300)$ \\
\hline $\operatorname{VIXR}_{t-1}$ & $-0.2217^{* * *}$ & $(-15.778)$ & $0.2433^{* * *}$ & ( 6.754) \\
\hline VIXR $_{t-2}$ & $-0.1978^{* * *}$ & $(-14.050)$ & $0.2246^{* * *}$ & ( 6.319) \\
\hline $\mathrm{VIXR}_{\mathrm{t}-3}$ & $-0.1800^{* * *}$ & $(-12.824)$ & $0.2088^{* * *}$ & ( 5.970) \\
\hline $\operatorname{VIXR}_{t-4}$ & $-0.1677^{* * *}$ & $(-12.055)$ & $0.1777^{* * *}$ & ( 5.209) \\
\hline $\operatorname{VIXR}_{t-5}$ & $-0.1472^{* * *}$ & $(-10.674)$ & $0.1537^{* * *}$ & ( 4.629$)$ \\
\hline VIXR $_{t-6}$ & $-0.1376^{* * *}$ & $(-10.185)$ & $0.1424^{* * *}$ & ( 4.437) \\
\hline $\mathrm{FR}_{\mathrm{t}-1}$ & $-0.3986^{* * *}$ & $(-10.412)$ & $-0.4089^{* * *}$ & $(-5.226)$ \\
\hline $\mathrm{FR}_{\mathrm{t}-2}$ & $-0.3540^{* * *}$ & $(-9.325)$ & $-0.3731^{* * *}$ & $(-4.850)$ \\
\hline $\mathrm{FR}_{\mathrm{t}-3}$ & $-0.3154^{* * *}$ & $(-8.409)$ & $-0.3365^{* * *}$ & $(-4.483)$ \\
\hline $\mathrm{FR}_{\mathrm{t}-4}$ & $-0.2771^{* * *}$ & $(-7.514)$ & $-0.3194^{* * *}$ & $(-4.401)$ \\
\hline $\mathrm{FR}_{\mathrm{t}-5}$ & $-0.2508^{* * *}$ & $(-6.946)$ & $-0.2448^{* * *}$ & $(-3.494)$ \\
\hline $\mathrm{FR}_{\mathrm{t}-6}$ & $-0.2149^{* * *}$ & $(-6.124)$ & $-0.2169^{* * *}$ & $(-3.225)$ \\
\hline Adj. R-squared & \multicolumn{2}{|l|}{0.520} & \multicolumn{2}{|l|}{0.486} \\
\hline \multicolumn{5}{|l|}{ Cointegrating Equation } \\
\hline $\mathrm{FR}_{\mathrm{t}-1}$ & $-2.7366^{* * *}$ & $(-15.605)$ & $2.1741^{* * *}$ & ( 9.744) \\
\hline
\end{tabular}

Notes:

$1 .{ }^{* * *},{ }^{* *}$ and ${ }^{*}$ denote significance at $1 \%, 5 \%$ and $10 \%$ levels, respectively.

2. t-statistics are shown in parentheses. 
Table 7. Results of the TVECM model for VIXR and CBSR

\begin{tabular}{|c|c|c|c|c|}
\hline \multirow{2}{*}{$\overline{\text { VIXR equation }}$} & \multicolumn{2}{|c|}{ Regime 1} & \multicolumn{2}{|c|}{ Regime 2} \\
\hline & & & & \\
\hline $\mathrm{Z}_{\mathrm{t}-1}$ & $-0.1397^{* * *}$ & $(-4.140)$ & -0.0088 & $(-0.298)$ \\
\hline $\operatorname{VIXR}_{t-1}$ & $-0.9832^{* * *}$ & $(-27.296)$ & $-0.9653^{* * *}$ & $(-25.424)$ \\
\hline $\operatorname{VIXR}_{t-2}$ & $-0.9876^{* * *}$ & $(-25.524)$ & $-0.9382^{* * *}$ & $(-21.141)$ \\
\hline $\operatorname{VIXR}_{t-3}$ & $-0.9739^{* * *}$ & $(-23.732)$ & $-0.8474^{* * *}$ & $(-17.009)$ \\
\hline $\operatorname{VIXR}_{t-4}$ & $-0.9776^{* * *}$ & $(-22.678)$ & $-0.8535^{* * *}$ & $(-15.855)$ \\
\hline $\operatorname{VIXR}_{t-5}$ & $-0.9616^{* * *}$ & $(-21.421)$ & $-0.7689^{* * *}$ & $(-13.242)$ \\
\hline VIXR $_{t-6}$ & $-0.9645^{* * *}$ & $(-20.783)$ & $-0.7491^{* * *}$ & $(-12.204)$ \\
\hline $\mathrm{CBSR}_{\mathrm{t}-1}$ & $0.1411^{* * *}$ & (4.038) & 0.0258 & $(0.339)$ \\
\hline $\mathrm{CBSR}_{\mathrm{t}-2}$ & $0.1393^{* * *}$ & $(4.035)$ & 0.0392 & $(0.522)$ \\
\hline $\mathrm{CBSR}_{\mathrm{t}-3}$ & $0.1403^{* * *}$ & $(4.120)$ & 0.0424 & $(0.574)$ \\
\hline $\mathrm{CBSR}_{\mathrm{t}-4}$ & $0.1370^{* * *}$ & ( 4.088) & 0.0442 & ( 0.607) \\
\hline $\mathrm{CBSR}_{\mathrm{t}-5}$ & $0.1308^{* * *}$ & ( 3.968$)$ & 0.0383 & $(0.536)$ \\
\hline $\mathrm{CBSR}_{\mathrm{t}-6}$ & $0.1285^{* * *}$ & ( 3.972$)$ & 0.0383 & $(0.547)$ \\
\hline Adj. R-squared & \multicolumn{2}{|c|}{0.583} & \multicolumn{2}{|l|}{0.501} \\
\hline \multicolumn{5}{|l|}{ CBSR equation } \\
\hline $\mathrm{Z}_{\mathrm{t}-1}$ & $-3.1668^{* * *}$ & $(-14.787)$ & $-1.4162^{* * *}$ & $(-8.460)$ \\
\hline $\operatorname{VIXR}_{t-1}$ & $3.0592^{* * *}$ & $(13.377)$ & $1.2419^{* * *}$ & ( 5.786) \\
\hline $\operatorname{VIXR}_{\mathrm{t}-2}$ & $2.9891^{* * *}$ & $(12.167)$ & $0.8350^{* * *}$ & (3.328) \\
\hline $\operatorname{VIXR}_{t-3}$ & $2.8642^{* * *}$ & ( 10.993) & $0.6550^{* *}$ & (2.326) \\
\hline VIXR $_{t-4}$ & $2.6756^{* * *}$ & $(9.775)$ & $0.6139^{* *}$ & (2.017) \\
\hline VIXR $_{t-5}$ & $2.4387^{* * *}$ & $(8.556)$ & $0.6446^{* *}$ & ( 1.964$)$ \\
\hline $\operatorname{VIXR}_{\mathrm{t}-6}$ & $2.3892^{* * *}$ & (8.109) & 0.4762 & ( 1.372$)$ \\
\hline $\mathrm{CBSR}_{\mathrm{t}-1}$ & $2.0689^{* * *}$ & ( 9.326) & $2.3649^{* * *}$ & ( 5.508$)$ \\
\hline $\mathrm{CBSR}_{\mathrm{t}-2}$ & $1.8673^{* * *}$ & $(8.521)$ & $2.1501^{* * *}$ & ( 5.071) \\
\hline $\mathrm{CBSR}_{\mathrm{t}-3}$ & $1.7129^{* * *}$ & ( 7.926) & $2.0038^{* * *}$ & ( 4.797) \\
\hline $\mathrm{CBSR}_{\mathrm{t}-4}$ & $1.5551^{* * *}$ & ( 7.306) & $1.8577^{* * *}$ & ( 4.523) \\
\hline $\mathrm{CBSR}_{\mathrm{t}-5}$ & $1.4069^{* * *}$ & ( 6.722) & $1.6987^{* * *}$ & ( 4.214) \\
\hline $\mathrm{CBSR}_{\mathrm{t}-6}$ & $1.2745^{* * *}$ & ( 6.203$)$ & $1.5767^{* * *}$ & (3.994) \\
\hline Adj. R-squared & \multicolumn{2}{|c|}{0.650} & \multicolumn{2}{|l|}{0.664} \\
\hline \multicolumn{5}{|c|}{ Cointegrating Equation } \\
\hline $\mathrm{CBSR}_{\mathrm{t}-1}$ & $1.0468^{* * *}$ & $(14.432)$ & $2.5878^{* * *}$ & $(8.530)$ \\
\hline
\end{tabular}

Notes:

$1 .{ }^{* * *},{ }^{* *}$ and ${ }^{*}$ denote significance at $1 \%, 5 \%$ and $10 \%$ levels, respectively.

2. t-statistics are shown in parentheses. 
Table 8. Results of the TVECM model for VIXR and PBSR

\begin{tabular}{|c|c|c|c|c|}
\hline & \multicolumn{2}{|c|}{ Regime 1} & \multicolumn{2}{|c|}{ Regime 2} \\
\hline \multicolumn{5}{|l|}{ VIXR equation } \\
\hline $\mathrm{Z}_{\mathrm{t}-1}$ & $-0.0121^{* *}$ & $(-2.289)$ & $-0.1424^{* * *}$ & $(-3.345)$ \\
\hline $\operatorname{VIXR}_{t-1}$ & $-1.1107^{* * *}$ & $(-76.869)$ & $-0.8439^{* * *}$ & $(-17.489)$ \\
\hline $\operatorname{VIXR}_{t-2}$ & $-1.1153^{* * *}$ & $(-53.342)$ & $-0.8176^{* * *}$ & $(-15.325)$ \\
\hline $\operatorname{VIXR}_{t-3}$ & $-1.0963^{* * *}$ & $(-42.598)$ & $-0.7331^{* * *}$ & $(-12.639)$ \\
\hline $\operatorname{VIXR}_{t-4}$ & $-1.0984^{* * *}$ & $(-37.090)$ & $-0.7479^{* * *}$ & $(-12.122)$ \\
\hline $\operatorname{VIXR}_{t-5}$ & $-1.0840^{* * *}$ & $(-32.954)$ & $-0.6753^{* * *}$ & $(-10.252)$ \\
\hline $\operatorname{VIXR}_{t-6}$ & $-1.0849^{* * *}$ & $(-30.355)$ & $-0.6537^{* * *}$ & $(-9.412)$ \\
\hline $\operatorname{PBSR}_{\mathrm{t}-1}$ & $0.0331^{* *}$ & $(2.362)$ & $-0.0404^{* * *}$ & $(-3.515)$ \\
\hline $\operatorname{PBSR}_{\mathrm{t}-2}$ & $0.0319^{* *}$ & $(2.314)$ & $-0.0403^{* * *}$ & $(-3.581)$ \\
\hline $\mathrm{PBSR}_{\mathrm{t}-3}$ & $0.0321^{* *}$ & $(2.372)$ & $-0.0382^{* * *}$ & $(-3.473)$ \\
\hline $\mathrm{PBSR}_{\mathrm{t}-4}$ & $0.0309^{* *}$ & $(2.325)$ & $-0.0367^{* * *}$ & $(-3.411)$ \\
\hline $\mathrm{PBSR}_{\mathrm{t}-5}$ & $0.0319^{* *}$ & $(2.448)$ & $-0.0359^{* * *}$ & $(-3.426)$ \\
\hline $\operatorname{PBSR}_{t-6}$ & $0.0302^{* *}$ & $(2.371)$ & $-0.0367^{* * *}$ & $(-3.606)$ \\
\hline Adj. R-squared & \multicolumn{2}{|c|}{0.575} & \multicolumn{2}{|c|}{0.497} \\
\hline \multicolumn{5}{|l|}{ PBSR equation } \\
\hline $\mathrm{Z}_{\mathrm{t}-1}$ & $-0.7128^{* * *}$ & $(-14.858)$ & $5.4671^{* * *}$ & (9.645) \\
\hline $\operatorname{VIXR}_{t-1}$ & $0.6926^{* * *}$ & $(5.275)$ & $-5.9563^{* * *}$ & $(-9.272)$ \\
\hline $\operatorname{VIXR}_{t-2}$ & $0.6171^{* * *}$ & ( 3.248$)$ & $-6.0959^{* * *}$ & $(-8.583)$ \\
\hline $\operatorname{VIXR}_{t-3}$ & $0.6140^{* * *}$ & ( 2.625) & $-6.1945^{* * *}$ & $(-8.022)$ \\
\hline $\operatorname{VIXR}_{t-4}$ & 0.4083 & ( 1.517$)$ & $-6.7474^{* * *}$ & $(-8.215)$ \\
\hline $\operatorname{VIXR}_{t-5}$ & 0.3029 & ( 1.013$)$ & $-6.8748^{* * *}$ & $(-7.839)$ \\
\hline $\mathrm{VIXR}_{\mathrm{t}-6}$ & 0.1357 & $(0.417)$ & $-6.5178^{* * *}$ & $(-7.049)$ \\
\hline PBSR $_{t-1}$ & $0.8795^{* * *}$ & ( 6.910$)$ & $0.3903^{* *}$ & $(2.554)$ \\
\hline $\operatorname{PBSR}_{\mathrm{t}-2}$ & $0.8088^{* * *}$ & $(6.464)$ & $0.3709^{* *}$ & ( 2.477$)$ \\
\hline $\mathrm{PBSR}_{\mathrm{t}-3}$ & $0.7636^{* * *}$ & ( 6.214) & $0.4253^{* * *}$ & ( 2.904$)$ \\
\hline $\mathrm{PBSR}_{\mathrm{t}-4}$ & $0.7065^{* * *}$ & ( 5.859) & $0.3728^{* * *}$ & $(2.605)$ \\
\hline $\mathrm{PBSR}_{\mathrm{t}-5}$ & $0.6611^{* * *}$ & ( 5.593) & $0.3284^{* *}$ & (2.353) \\
\hline $\mathrm{PBSR}_{\mathrm{t}-6}$ & $0.6000^{* * *}$ & ( 5.179) & $0.3114^{* *}$ & ( 2.295) \\
\hline Adj. R-squared & \multicolumn{2}{|c|}{0.591} & \multicolumn{2}{|c|}{0.610} \\
\hline \multicolumn{5}{|c|}{ Cointegrating Equation } \\
\hline $\mathrm{PBSR}_{\mathrm{t}-1}$ & $2.6936^{* * *}$ & ( 14.949) & $-0.2754^{* * *}$ & $(-8.606)$ \\
\hline
\end{tabular}

Notes:

$1 .{ }^{* * *},{ }^{* *}$ and ${ }^{*}$ denote significance at $1 \%, 5 \%$ and $10 \%$ levels, respectively.

2. t-statistics are shown in parentheses. 
Table 9. Results of the TVECM model for VIXR and CPVR

\begin{tabular}{|c|c|c|c|c|}
\hline \multirow{2}{*}{$\overline{\text { VIXR equation }}$} & \multicolumn{2}{|c|}{ Regime 1} & \multicolumn{2}{|c|}{ Regime 2} \\
\hline & & & & \\
\hline$Z_{t-1}$ & 0.0012 & ( 1.048$)$ & $-0.1514^{* * *}$ & $(-3.462)$ \\
\hline $\operatorname{VIXR}_{t-1}$ & $-1.1204^{* * *}$ & $(-82.256)$ & $-0.8309^{* * *}$ & $(-16.570)$ \\
\hline $\mathrm{VIXR}_{\mathrm{t}-2}$ & $-1.1255^{* * *}$ & $(-55.208)$ & $-0.7977^{* * *}$ & $(-14.336)$ \\
\hline VIXR $_{t-3}$ & $-1.1072^{* * *}$ & $(-43.677)$ & $-0.7097^{* * *}$ & $(-11.788)$ \\
\hline VIXR $_{\mathrm{t}-4}$ & $-1.1093^{* * *}$ & $(-37.836)$ & $-0.7257^{* * *}$ & $(-11.375)$ \\
\hline VIXR $_{t-5}$ & $-1.0921^{* * *}$ & $(-33.437)$ & $-0.6500^{* * *}$ & $(-9.598)$ \\
\hline $\operatorname{VIXR}_{\mathrm{t}-6}$ & $-1.0924^{* * *}$ & $(-30.739)$ & $-0.6283^{* * *}$ & $(-8.839)$ \\
\hline $\mathrm{CPVR}_{\mathrm{t}-1}$ & -0.0146 & $(-1.083)$ & $0.0358^{* * *}$ & (3.511) \\
\hline $\mathrm{CPVR}_{\mathrm{t}-2}$ & -0.0138 & $(-1.043)$ & $0.0345^{* * *}$ & ( 3.454$)$ \\
\hline $\mathrm{CPVR}_{\mathrm{t}-3}$ & -0.0140 & $(-1.080)$ & $0.0335^{* * *}$ & (3.436) \\
\hline $\mathrm{CPVR}_{\mathrm{t}-4}$ & -0.0120 & $(-0.944)$ & $0.0328^{* * *}$ & (3.446) \\
\hline $\mathrm{CPVR}_{\mathrm{t}-5}$ & -0.0157 & $(-1.271)$ & $0.0317^{* * *}$ & ( 3.416$)$ \\
\hline $\mathrm{CPVR}_{\mathrm{t}-6}$ & -0.0128 & $(-1.058)$ & $0.0311^{* * *}$ & ( 3.423$)$ \\
\hline Adj. R-squared & \multicolumn{2}{|c|}{0.577} & \multicolumn{2}{|c|}{0.492} \\
\hline \multicolumn{5}{|l|}{ CPVR equation } \\
\hline$Z_{t-1}$ & $-0.1733^{* * *}$ & $(-15.761)$ & $-7.1163^{* * *}$ & $(-9.793)$ \\
\hline VIXR $_{t-1}$ & 0.0871 & $(0.685)$ & $7.2836^{* * *}$ & ( 8.742) \\
\hline $\mathrm{VIXR}_{\mathrm{t}-2}$ & 0.1160 & ( 0.609) & $6.4617^{* * *}$ & ( 6.988$)$ \\
\hline VIXR $_{t-3}$ & 0.1388 & $(0.586)$ & $6.5869^{* * *}$ & ( 6.584$)$ \\
\hline VIXR $_{t-4}$ & 0.2008 & $(0.733)$ & $6.6971^{* * *}$ & ( 6.317) \\
\hline VIXR $_{t-5}$ & 0.0956 & $(0.313)$ & $7.0809^{* * *}$ & ( 6.292) \\
\hline VIXR $_{t-6}$ & 0.2306 & $(0.695)$ & $7.1540^{* * *}$ & $(6.056)$ \\
\hline $\mathrm{CPVR}_{\mathrm{t}-1}$ & $0.9727^{* * *}$ & ( 7.738) & $0.6269^{* * *}$ & (3.703) \\
\hline $\mathrm{CPVR}_{\mathrm{t}-2}$ & $0.9050^{* * *}$ & ( 7.339) & $0.4803^{* * *}$ & ( 2.895$)$ \\
\hline $\mathrm{CPVR}_{\mathrm{t}-3}$ & $0.8470^{* * *}$ & ( 7.011) & $0.4618^{* * *}$ & ( 2.847) \\
\hline $\mathrm{CPVR}_{\mathrm{t}-4}$ & $0.8019^{* * *}$ & ( 6.784$)$ & $0.4418^{* * *}$ & $(2.791)$ \\
\hline $\mathrm{CPVR}_{\mathrm{t}-5}$ & $0.7375^{* * *}$ & ( 6.383) & $0.4037^{* * *}$ & (2.614) \\
\hline $\mathrm{CPVR}_{\mathrm{t}-6}$ & $0.6860^{* * *}$ & ( 6.079) & $0.3865^{* *}$ & ( 2.564$)$ \\
\hline Adj. R-squared & & & & \\
\hline \multicolumn{5}{|c|}{ Cointegrating Equation } \\
\hline $\mathrm{CPVR}_{\mathrm{t}-1}$ & $11.6343^{* * *}$ & $(15.835)$ & $0.2376^{* * *}$ & ( 8.665$)$ \\
\hline
\end{tabular}

Notes:

$1 .{ }^{* * *},{ }^{* *}$ and ${ }^{*}$ denote significance at $1 \%, 5 \%$ and $10 \%$ levels, respectively.

2. t-statistics are shown in parentheses. 


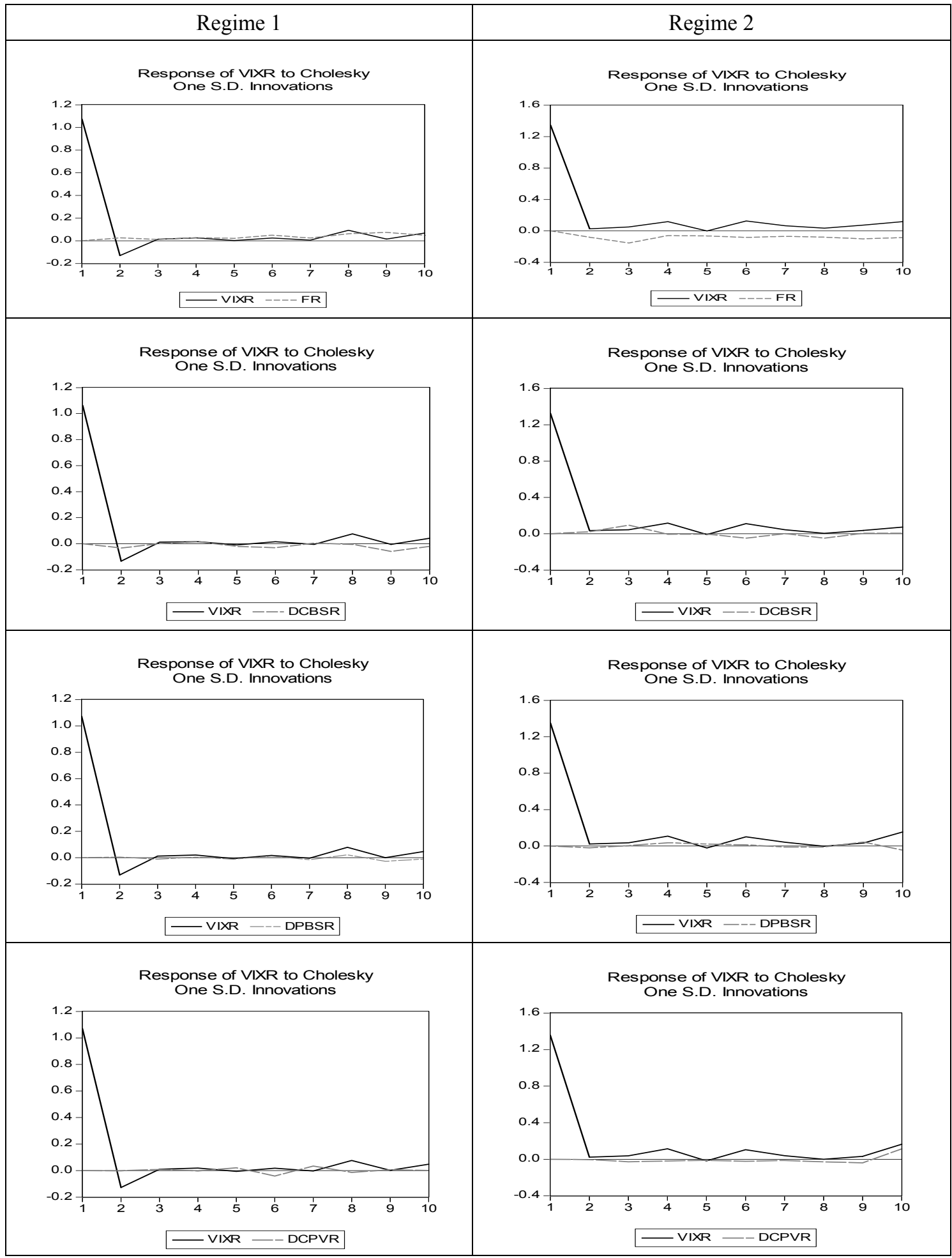

Figure 1. Non-linear impulse response of VIXR to Cholesky

One S.D. Innovations with respect to FR, CBSR, PBSR, CPVR in two regimes

\section{Conclusion}

The research results show that VIXR, FR, CBSR, PBSR and CPVR have different long-run equilibrium relationships and adjustment speed in different regimes. VIXR and FR have two way lead-lag relationships in both regimes 1 and 2. VIXR and CBSR have two way lead-lag relationships in regime 2; and lagged CBSR leads VIXR in regime 1. VIXR and PBSR have two way lead-lag relationships in regimes 1 and 2. VIXR and CPVR have two lead-lag 
relationships in regime 2 .

In regime 1, lagged VIXR has negative significant impacts on FR, positive significant impacts on PBSR, positive significant impacts on CPVR. In regime 2, lagged VIXR has positive significant impacts on FR, negative significant impacts on PBSR, positive significant impacts on CPVR. In regime 1, lagged FR has negative significant impacts on VIXR, lagged CBSR has positive significant impacts on VIXR, lagged PBSR has positive significant impacts on VIXR, and lagged CPVR has positive significant impacts on VIXR. In regime 2, lagged FR has positive significant impacts VIXR, lagged CBSR has negative significant impacts VIXR, lagged PBSR has negative significant impacts VIXR, and lagged CPVR has positive significant impacts on VIXR.

The impact of lagged VIXR on FR is negative in regime 1, and becomes positive in regime 2. The impact of lagged VIXR on PBSR is positive in regime 1, and becomes negative in regime 2. The impact of lagged VIXR on CPVR remains positive in both regimes. The impact of lagged FR on VIXR is negative in regime 1, and becomes positive in regime 2. The impact of lagged CBSR on VIXR is positive in regime 1, and becomes negative in regime 2. The impact of lagged PBSR on VIXR is positive in regime 1, and becomes negative in regime 2 . The impact of CPVR on VIXR remains positive in both regimes.

The results of this paper show that, using VIX as threshold, the impacts of lagged VIXR on FR, lagged VIXR on PBSR, lagged FR on VIXR, lagged CBSR on VIXR, and lagged PBSR on VIXR all have asymmetric results. These findings support the results of Whaley (2009). The results also support Corrado \& Miller (2005) and Carr \& Wu (2006) who show that VIX index (implied volatility in the options markets) provides good forecast quality in the derivatives markets. And the results provide evidence of two-way lead-lag relationships between VIX and futures price.

\section{References}

Antoniou, A., Pescetto, G., \& Violaris, A. (2003). Modeling international price relationships and interdependencies between stock index and stock index futures markets of three EU countries: A multivariate analysis. Journal of Business Finance and Accounting, 30, 645-667. http://dx.doi.org/10.1111/1468-5957.05409

Athanasios, V. (2010). Lead-Lag relationship between futures market and spot market. Evidence from the Greek stock and derivative market. International Research Journal of Finance and Economics, 41, 163-176.

Balke, N. S., \& Fomby, T. B. (1997). Threshold cointegration. International Economic Review, 38, 627-645. http://dx.doi.org/10.2307/2527284

Bohl, M. T., Salm, C. A., \& Schuppli, M. (2011). Price discovery and investor structure in stock index futures. Journal of Futures Markets, 31, 282-306. http://dx.doi.org/10.1002/fut.20469

Carr, P., \& Wu, L. (2006). A tale of two indices. Journal of Derivatives, 13, 13-29. http://dx.doi.org/10.3905/jod.2006.616865

Chan, K. (1992). A further analysis of the lead-lag relationship between the cash market and stock index futures market. Review of Financial Studies, 5, 123-152. http://dx.doi.org/10.1093/rfs/5.1.123

Chung, S. L., Tsai, W. C., Wang, Y. H. \& Weng, P. S. (2011). The information content of the S\&P 500 index and VIX options on the dynamics of the S\&P 500 index. Journal of Futures Markets, 31, 1170-1201. http://dx.doi.org/10.1002/fut.20532

Christensen, B.J. \& Hansen, C.S. (2002). New Evidence on the Implied-Realized Volatility Relation. European Journal of Finance, 8, 187-205. http://10.1080/13518470110071209

Corrado, C. J., \& Miller, T. W. (2005). The forecast quality of CBOE implied volatility indexes. Journal of Futures Markets, 25, 339-373. http://dx.doi.org/10.1002/fut.20148

Dennis, P., Mayhew, S., \& Stivers, C. (2006). Stock returns, implied volatility innovations, and the asymmetric volatility phenomenon. Journal of Financial and Quantitative Analysis, 41, 381-406. http://dx.doi.org/10.1017/S0022109000002118

Durand, R. B., Lim, D., \& Zumwalt, J. K. (2011). Fear and the Fama-French factors. Financial Management, 40, 409-426. http://dx.doi.org/10.1111/j.1755-053X.2011.01147.x

Enders, W., \& Granger, C. W. F. (1998). Unit-root tests and asymmetric adjustment with an example using the term structure of interest rates. Journal of Business Economics and Statistics, 16, 304-311.

Enders, W., \& Siklos, P. L. (2001). Cointegration and threshold adjustment. Journal of Business Economics and Statistics , 19, 166-176. http://dx.doi.org/10.1198/073500101316970395

Engle, R. F., \& Granger, C. W. J. (1987). Cointegration and error correction: Representation, estimation and testing. Econometrica, 55, 251-276. http://dx.doi.org/10.2307/1913236

Finnerty, J. E., \& Park, H. Y. (1987). Stock index futures: Does the tail wag the dog? Financial Analysts Journal, 43, 57-61. http://dx.doi.org/10.2469/faj.v43.n2.57 
Fleming, J., Ostdiek, B., \& Whaley, R.E. (1995). Predicting stock market volatility: A new measure. Journal of Futures Markets, 15, 265-302. http://dx.doi.org/10.1002/fut.3990150303

Gannon, G. (2005). Simultaneous volatility transmissions and spillover effects: U. S. and Hong Kong stock and futures markets. International Review of Financial Analysis, 14, 326-336. http://dx.doi.org/10.1016/j.irfa.2004.10.005

Hansen, B. E., \& Seo, B. (2002). Testing for two-regime threshold cointegration in vector error correction models. Journal of Econometrics, 110, 293-318. http://dx.doi.org/10.1016/S0304-4076(02)00097-0

Hanson, C. S. (2001). The relation between implied and realized volatility in the Danish option and equity markets. Accounting and Finance, 41, 197-228. http://dx.doi.org/10.1111/1467-629X.00059

Herbst, A. F., McCormack, J. P., \& West, E. N. (1987). Investigation of a lead-lag relationship between spot stock indices and their futures contracts. Journal of Futures Markets, 7, 373-381. http://dx.doi.org/10.1002/fut.3990070403

Huang, C. H., Chang, K. F., \& Wang, C. H. (2013). The effects of Taiwan VIX index on the intraday ordering behavior of stock index options. Review of Futures Markets, 21, 111-143.

Illueca, M. \& Lafuente, J. A. (2007), The effect of futures trading on the distribution of spot index returns: Implications for CVar in the Spanish market. Journal of Futures Markets, 27, 839-866. http://dx.doi.org/10.1002/fut.20271

Karpoff, J. M. (1987). The relation between price changes and trading volume: A survey. Journal of Financial and Quantitative Analysis, 22, 109-126. http://dx.doi.org/10.2307/2330874

Kavussanos, M. G., Visvikis, I. D., \& Alexakis, P. D. (2008). The lead-lag relationship between cash and stock index futures in a new market. European Financial Management, 14, 1007-1025. http://10.1111/j.1468-036X.2007.00412.x

Kawaller, I.G., Koch, P.D., \& Koch, T.W. (1987). The Temporal Price Relationship between S\&P Futures and the S\&P 500 Index. Journal of Finance, 42, 1309-1329. http:// 10.1111/j.1540-6261.1987.tb04368.x

Lee, B. S., \& Rui, O. M. (2002). The dynamic relationship between stock returns and trading volume: Domestic and cross-country evidence. Journal of Banking and Finance, 26, 51-78. http://dx.doi.org/10.1016/S0378-4266(00)00173-4

MacKinnon, J. G., \& Haug, A. A. (1999). Numerical distribution functions of likelihood ratio tests for cointegration. $\begin{array}{lllll}\text { Journal of } & \text { Applied } & \text { Econometrics, } & \text { 14, } & \text { 563-577. }\end{array}$ http://dx.doi.org/10.1002/(SICI)1099-1255(199909/10)14:5<563::AID-JAE530>3.0.CO;2-R

McMillian, D.G., \& Speight, A. E. H. (2006). Nonlinear dynamics and competing behavior interpretations: Evidence from intra-day FTSE-100 index and futures data. Journal of Futures Markets, 26, 343-368. http://dx.doi.org/10.1002/fut.20203

Mayhew, S., \& Stivers, C. (2003). Stock return dynamics, option volume, and the information content of implied volatility. Journal of Futures Markets, 23, 615-646. http://dx.doi.org/10.1002/fut.10084

Park, T. H., Switzer, L. N., \& Bedrossian, R. (1999). The interactions between trading volume and volatility: Evidence from the equity options markets. Applied Financial Economics, 9, 627-637. http://dx.doi.org/10.1080/096031099332078

Phillips, P. C. B., \& Perron, P. (1988). Testing for a unit root in time series regression. Biometrika, 75, 335-346. http://dx.doi.org/10.1093/biomet/75.2.335

Sarno, L., \& Valente, G. (2000). The cost of carry model and regime shifts in stock index futures markets: an empirical investigation. Journal of Futures Markets, 20, 603-624. http://dx.doi.org/10.1002/1096-9934(200008)20:7<603::AID-FUT1>3.0.CO;2-X

Shu, J., \& Zhang, J. E. (2012). Causality in the VIX futures market. Journal of Futures Markets, 32, 24-46. http://dx.doi.org/10.1002/fut.20506

Sims, C. A. (1988). Bayesian skepticism on unit root econometrics. Journal of Economic Dynamics and Control, 12, 463-474. http://dx.doi.org/10.1016/0165-1889(88)90050-4

Stoll, H., \& Whaley, R. (1990). The dynamics of stock and stock index futures returns. Journal of Financial and Quantitative Analysis, 25, 441-468. http://dx.doi.org/10.2307/2331010

Wagner, N., \& Marsh, T. A. (2005). Surprise volume and heteroskedasticity in equity market returns. Quantitative Finance, 5, 153-168. http://dx.doi.org/10.1080/14697680500147978

Whaley, R. E. (2009). Understanding the VIX. Journal of Portfolio Management, 35, 98-105. http://dx.doi.org/10.3905/JPM.2009.35.3.098

Yang, J., Yang, Z., \& Zhou, Y. (2012). Intraday price discovery and volatility transmission in stock index and stock index futures markets: Evidence from China, Journal of Futures Markets, 32, 99-121. http://dx.doi.org/10.1002/fut.20514 